\title{
Transactions
}

Cite this: Dalton Trans., 2012, 41, 783

wWW.rsc.org/dalton

PAPER

\section{Ni(II) and Pd(II) pyridinyloxazolidine-compounds: synthesis, X-ray characterisation and catalytic activities in the aza-Michael reaction $\uparrow$}

\author{
G. Attilio Ardizzoia, ${ }^{a}$ Stefano Brenna ${ }^{* a}$ and Bruno Therrien ${ }^{b}$ \\ Received 23rd June 2011, Accepted 22nd September 2011 \\ DOI: $10.1039 /$ c1dt11191d
}

The 3-phenyl-2-(pyridin-2-yl)oxazolidine ligand (ppo) was synthesised and its coordination behaviour regarding $\mathrm{Ni}(\mathrm{II})$ and $\mathrm{Pd}(\mathrm{II})$ centres was studied. The reaction with $\mathrm{K}_{2} \mathrm{PdCl}_{4}$ affords $\left[\mathrm{Pd}\left(N, N^{\prime}\right.\right.$-ppo) $\left.\mathrm{Cl}_{2}\right]$ (1), in which ppo binds to palladium via the pyridyl nitrogen and the oxazolyl nitrogen atoms. On the contrary, reaction with $\mathrm{NiCl}_{2} \cdot 6 \mathrm{H}_{2} \mathrm{O}$ produces $\left[\mathrm{Ni}(\mathrm{N}, \mathrm{O} \text {-ppo })_{2} \mathrm{Cl}_{2}\right](2)$, in which two ppo ligands are coordinated via the pyridyl nitrogen and the oxygen atom of the oxazolidine ring. The X-ray diffraction analysis of the complexes confirms a square planar geometry for $\mathrm{Pd}(\mathrm{II})$ in $\mathbf{1}$ and an octahedral configuration around $\mathrm{Ni}$ (II) in $\mathbf{2}$, which, to the best of our knowledge, represents the first reported example of a structurally characterised nickel-oxazolidine compound. In addition, both complexes prove to be active catalysts under mild conditions in the aza-Michael reaction of (E)-4-phenylbut-3-en-2-one (benzalacetone) with aliphatic amines.

\section{Introduction}

The rational design of coordination compounds can often be achieved by the use of suitable heteropolydentate ligands. ${ }^{1}$ Among others, nitrogen-containing heterocyclic ligands have been very purposeful in the synthesis of diverse types of complexes showing mixed structures and bonding. ${ }^{2}$ In this field, despite the large use of oxazoline-based compounds, ${ }^{3}$ little has been reported on their saturated counterpart, oxazolidines. The interest in the use of these derivatives in coordination chemistry is mostly related to the presence of two potential donor sites ( $\mathrm{N}$ and $\mathrm{O}$ ) together with the ease of ring-functionalisation by varying the starting materials. For instance, oxazolidines are conveniently prepared by condensation of aldehydes with $\beta$-amino alcohols and the large accessibility of the latter in enantiopure form (e.g. ephedrine derivatives) facilitates the synthesis of a wide variety of chiral oxazolidine-based ligands. ${ }^{4}$

Examples of the use of oxazolidine-containing compounds in catalytic reactions are the enantioselective addition of $\mathrm{Et}_{2} \mathrm{Zn}$ to aldehydes, ${ }^{5}$ the Ru-catalysed epoxidation of olefins ${ }^{6}$ and the allylic substitution mediated by palladium. ${ }^{7}$ Importantly, the majority of these catalysts are prepared in situ, and only a few papers report the isolation and crystallographic characterisation of oxazolidine-complexes. The first structure of a compound containing an $\mathrm{NH}$ coordinated oxazolidine dates back to $1992,{ }^{8}$

${ }^{a}$ Dipartimento di Scienze Chimiche e Ambientali, Università degli Studi dell'Insubria, Via Valleggio, 11-22100, Como, Italy

${ }^{b}$ Service Analytique Facultaire, Université de Neuchâtel, Ave de Bellevaux 51, CH-2000, Neuchâtel, Switzerland

$\dagger$ Electronic supplementary information (ESI) available. CCDC reference numbers 830383 and 830384 . For ESI and crystallographic data in CIF or other electronic format see DOI: $10.1039 /$ cldt11191d whereas some more recent reports on the structural description of phosphinoxazolidine-palladium ${ }^{9}$ and rhodium $^{10}$ species appeared. Finally, a paper by Jones ${ }^{11}$ and co-workers has described the only two known crystalline structures of transition metal complexes bearing pyridinyl-oxazolidine derivatives: these examples being summarised in Chart 1.<smiles>Pc1cccc([C@H]2OC(c3ccccc3)(c3ccccc3)[C@H]3CCCN23)c1P</smiles><smiles>[R7]C1([R7])C[C@@H]2[C@H](c3ccccc3)OC(c3ccccc3P)(c3ccccc3P)N2C1</smiles><smiles>Pc1ccccc1C1OC(c2ccccc2)(c2ccccc2)C2C3CCC(C3)N12</smiles>

Nakano's phosphinoxazolidine ligands<smiles>CC(C)C[C@@H]1COC(c2ccc(Cl)cc2)N1[PH](Cl)P[Pb](Cl)c1ccccc1</smiles><smiles></smiles>

Palladium $\mathrm{NH}$-adduct.<smiles></smiles>

Jones' pyridinyloxazolidinepalladium complexes

Chart 1 Structurally characterised oxazolidine-based ligands or complexes. 
We recently initiated a study on the coordination chemistry of fully saturated $\mathrm{N}$-containing heterocylces and we have already reported on the coordination chemistry of dihydrobenzoxazinetype ligands towards copper ${ }^{12}$ and group- 12 metals. ${ }^{13}$ To continue this study, we have now tested the coordination chemistry of ligands based on five-membered rings, specifically those containing an oxazolidine skeleton. Herein we report the coordination chemistry of 3-phenyl-2-(pyridin-2-yl)oxazolidine (ppo) towards $\mathrm{Pd}(\mathrm{II})$ and $\mathrm{Ni}(\mathrm{II})$ centres. The versatility displayed by the ligand, which coordinates in a different chelating mode depending on the metal centre is presented (Chart 2). ${ }^{14}$ The X-ray structure analysis of these complexes includes what, to the best of our knowledge, is the first example of a crystallographic description of a nickel-oxazolidine compound. Finally, the synthesised species have been tested as catalysts in the conjugate addition of aliphatic amines to $(E)$-4-phenyl-but-3-en-2-one (benzalacetone) under mild conditions.

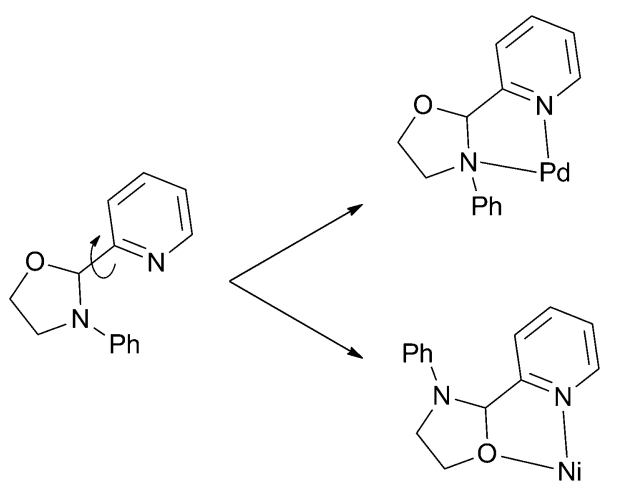

Chart 2 Schematic representation of the different chelating coordination modes displayed by 3-phenyl-2-(pyridin-2-yl)oxazolidine (ppo).

\section{Results and discussion}

\section{Synthesis of 3-phenyl-2-(pyridin-2-yl)oxazolidine (ppo)}

The ligand ppo is prepared following a reported procedure ${ }^{15}$ by heating at $70{ }^{\circ} \mathrm{C}$ in ethanol an equimolar mixture of 2-anilino ethanol and 2-pyridinecarboxaldehyde (Scheme 1). The analysis of the ${ }^{1} \mathrm{H}$ and ${ }^{13} \mathrm{C}\left\{{ }^{1} \mathrm{H}\right\}$ NMR spectra $\left(\mathrm{CD}_{3} \mathrm{CN}, 25^{\circ} \mathrm{C}\right)$ confirms the formation of the desired product (see Scheme 1 for atom numbering). Specifically, the singlet at $5.87 \mathrm{ppm}$ is easily attributed to $\mathrm{H}-2$, while the diastereotopic $\mathrm{CH}_{2}$ groups in position 4 and 5 of the strained oxazolidine ring appear as multiplets centred at 3.72 and $4.23 \mathrm{ppm}$, respectively. The related ${ }^{13} \mathrm{C}$ resonances are observed at $93.3 \mathrm{ppm}(\mathrm{C}-2), 66.7 \mathrm{ppm}(\mathrm{C}-5)$ and $48.5 \mathrm{ppm}$ (C4). The ring-chain tautomerism typical of $\mathrm{N}-\mathrm{H}$-1,3-oxazolidines ${ }^{16}$ is in this case forbidden by the presence of the phenyl substituent

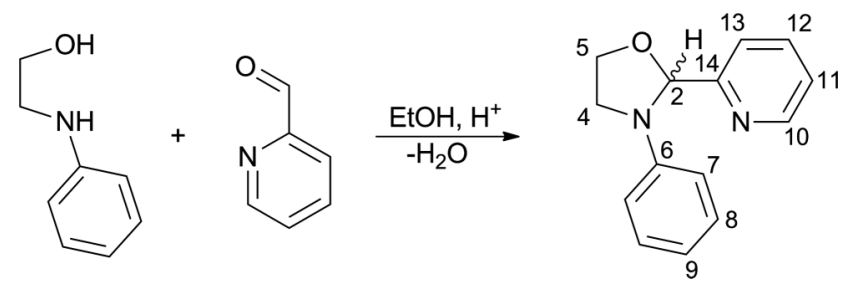

Scheme 1 Synthesis of ppo and relative atom numbering. on the starting $\beta$-amino alcohol. As a consequence, the closed heterocyclic form is the only one present in solution, and signals due to the corresponding iminic form are not detected in the NMR spectra.

It should be stressed that ppo possesses a stereogenic centre in position 2 of the oxazolidine ring. However, no efforts were made to isolate the ligand in an enantiomerically pure form, and ppo was always used as a racemic mixture.

\section{Synthesis and characterisation of the complexes}

The reaction of ppo with $\mathrm{K}_{2} \mathrm{PdCl}_{4}$ in a $1: 1$ molar ratio, in methanol at room temperature, gives a yellow-to-orange suspension, from which a yellow solid is isolated in good yields after filtration. Together with the singlet at $5.80 \mathrm{ppm}$ attributed to $\mathrm{H}-2$, the ${ }^{1} \mathrm{H} \mathrm{NMR}$ spectrum of 1 shows three aliphatic resonances corresponding to the protons of the $\mathrm{CH}_{2}$ groups at $3.25\left(\mathrm{H}_{\mathrm{a}}-4\right), 4.46\left(\mathrm{H}_{\mathrm{a}}-5\right)$ and $5.03\left(\mathrm{H}_{\mathrm{b}}-4 / 5\right) \mathrm{ppm}$, respectively (see ESI $\uparrow$ for signals attribution). The diastereotopic protons in positions 4 and 5 are markedly split with respect to the free ligand: $\mathrm{H}_{\mathrm{a}}-4$ and $\mathrm{H}_{\mathrm{b}}-4$ being respectively at 3.58 and $3.84 \mathrm{ppm}$, and $\mathrm{H}_{\mathrm{a}}-5$ and $\mathrm{H}_{\mathrm{b}}-5$ being both at $4.26 \mathrm{ppm}$ in free ppo. In the ${ }^{13} \mathrm{C}\left\{{ }^{1} \mathrm{H}\right\}$ NMR spectrum the signals relative to C-2, C-4 and C-5 are shifted downfield as compared to the free ligand (100.7, 58.0 and $66.9 \mathrm{ppm}$, in that order). The slightly higher splitting associated to $\mathrm{H}-4$ with respect to $\mathrm{H}-5$ suggests that ppo coordinates to palladium via the $\mathrm{N}$-atom of the oxazolidine ring, thus assuming an $N, N^{\prime}$ chelation mode (Fig. 1). Accordingly, the complex can be described as $\left[\mathrm{Pd}\left(N, N^{\prime}\right.\right.$-ppo $\left.) \mathrm{Cl}_{2}\right](\mathbf{1})$. This finding was further confirmed by the X-ray crystal structure analysis of $\mathbf{1}$ (Fig. 2).

Complex 1 crystallises in the centrosymmetric space group $P$ $2_{1} / c$ and crystals of $\mathbf{1}$ are found as racemates. The palladium atom adopts a square-planar geometry in which two chlorides and the two nitrogen atoms of the ppo ligand occupy the four coordination sites. Coordination of ppo in a $N, N^{\prime}$ chelating mode imposes distortion to the square-planar geometry, the N1$\mathrm{Pd} 1-\mathrm{N} 2$ angle being acute at $82.23(13)^{\circ}$. The $\mathrm{Pd}-\mathrm{N}$ distances are non-equivalent, the Pd N-pyridyl bond (2.031(3) $\AA$ ) is shorter than the Pd N-oxazolidine bond (2.095(3) $\AA$ ), which is consistent with those observed in the analogous complexes $\left[\mathrm{Pd}_{2}\left(N, N^{\prime}-\mathrm{L}\right)_{2} \mathrm{Cl}_{2}\right]\left(N, N^{\prime}-\mathrm{L}=3\right.$,4-dimethyl-5-phenyl-2(pyridine-2yl)oxazolidine $)^{11}$ and $\left[\mathrm{Pd}_{2}\left(N, N^{\prime}-\mathrm{L}^{\prime}\right)_{2} \mathrm{Cl}_{2}\right]\left(N, N^{\prime}-\mathrm{L}^{\prime}=3\right.$-benzyl-4methyl-5-phenyl-2(pyridine-2-yl)oxazolidine). ${ }^{17}$

This first outcome encouraged us to investigate as well the behaviour of ppo towards nickel(II). Treatment of a solution of $\mathrm{NiCl}_{2} \cdot 6 \mathrm{H}_{2} \mathrm{O}$ in acetonitrile at $60{ }^{\circ} \mathrm{C}$ with an equimolar amount of ppo affords a suspension from which a green solid could be easily recovered. The yield of the reaction is quite low (48\%) and the mother liquors remain green, most probably due to the presence of unreacted nickel chloride. This could only be explained by a stoichiometry different from $1: 1$ between ppo and the metal centre in the final nickel compound, as confirmed by the elemental analysis which gave a 1:2 nickel:ppo ratio. To further confirm this hypothesis, a second reaction with double the amount of ligand has been performed, resulting in the formation of the green compound in quantitative yield. This complex is then formulated as $\left[\mathrm{Ni}(\mathbf{p p o})_{2} \mathrm{Cl}_{2}\right]$ (2).

The configuration at the metal centre is determined by the $\mathrm{X}$-ray structure analysis of $\left[\mathrm{Ni}(\mathbf{p p o})_{2} \mathrm{Cl}_{2}\right]$. The crystals are obtained 

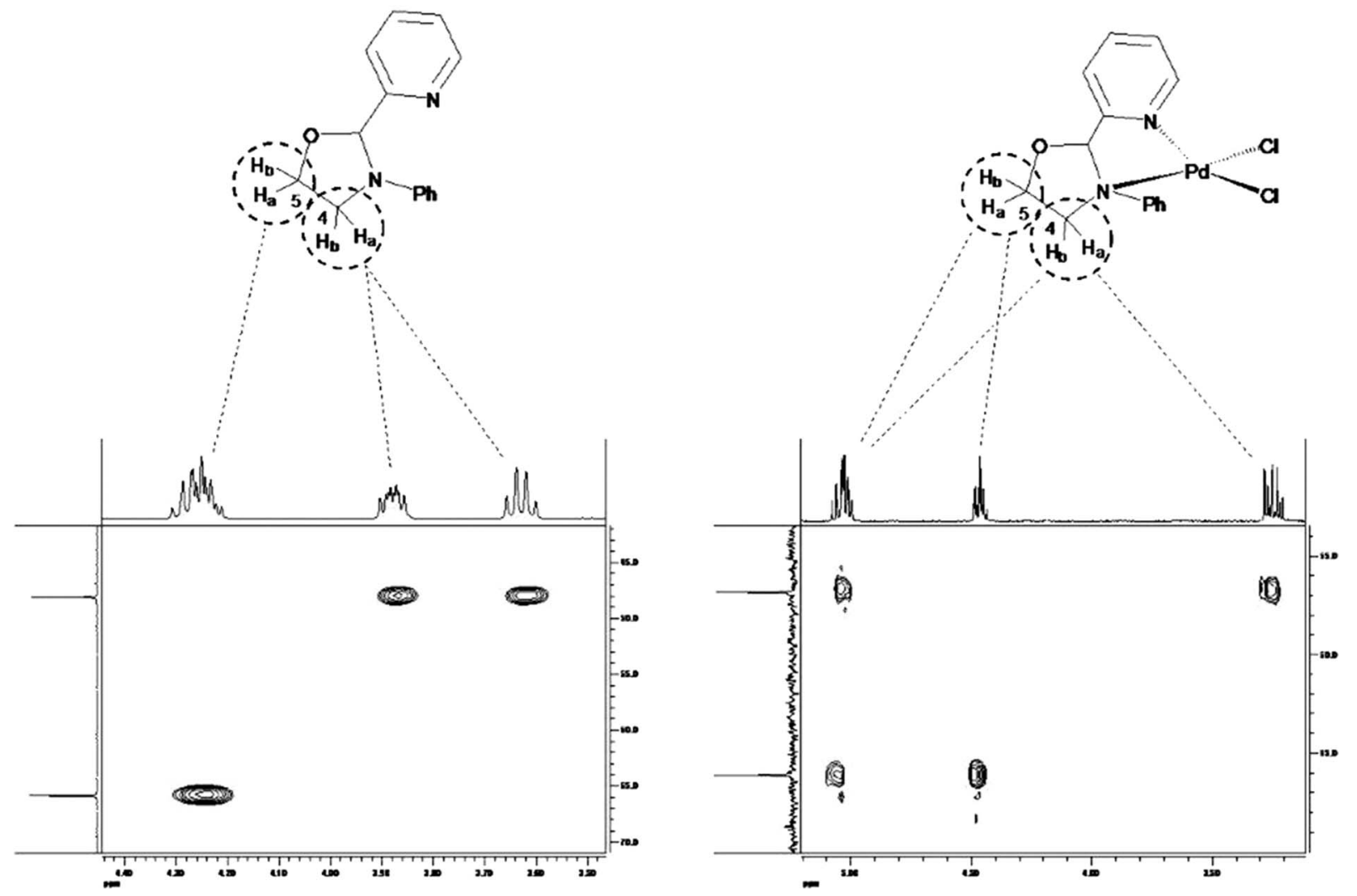

Fig. $1{ }^{1} \mathrm{H}-{ }^{13} \mathrm{C}$ HETCOR spectra of ppo (left) and $\mathbf{1}$ (right) in the aliphatic region. Dashed lines indicate $\mathrm{H}-4_{\mathrm{a} / \mathrm{b}}$ and $\mathrm{H}-5_{\mathrm{a} / \mathrm{b}}$ splitting in the free ligand and after coordination to palladium.

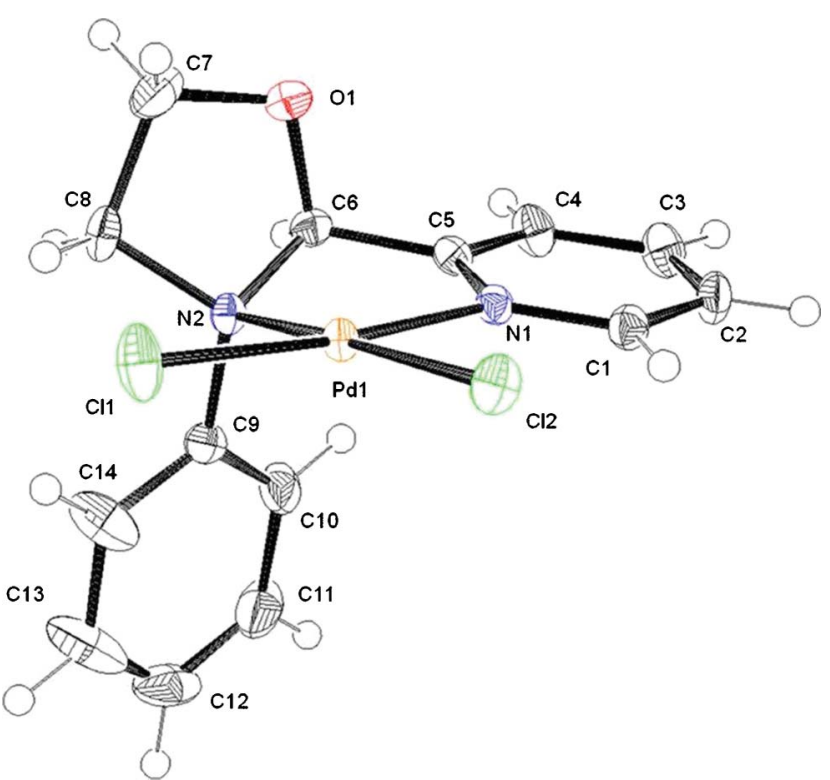

Fig. 2 ORTEP drawing of 1 (50\% probability level ellipsoids) with selected bond lengths $(\AA)$ and angles $\left(^{\circ}\right)$ : Pd1-Cl1 2.2982(11), Pd1-Cl2 2.2899(10), Pd1-N1 2.031(3), Pd1-N2 2.095(3); Cl1-Pd1-Cl2 90.22(4), Cl1-Pd1-N2 94.41(10), Cl2-Pd1-N1 93.40(10), N1-Pd1-N2 82.23(13).

by slow diffusion of diethylether into a DMF solution of 2 . In the crystal, the central Ni(II) atom is positioned on an inversion centre and the metal is surrounded by two ppo ligands and two chlorides (Fig. 3). Each molecule of ppo chelates the metal ion via the aromatic nitrogen of the pyridyl group and the oxygen of the oxazolidine part, thus being better described as chelating $N, O$ ppo ligands. Therefore, complex 2 is best formulated as [ $\mathrm{Ni}(\mathrm{N}, \mathrm{O}$ ppo) ${ }_{2} \mathrm{Cl}_{2}$ ]. To the best of our knowledge, this represents the sole example reported in the literature of a crystallographic investigation of a nickel-oxazolidine complex. Despite analogous systems previously described by $\mathrm{us}^{12,13}$ showing the $N, N^{\prime}$ coordination towards hard ions such as $\mathrm{Zn}^{2+}$ and $\mathrm{Cu}^{2+}$ (absolute hardness $(\mathrm{eV})$ : $\mathrm{Zn}^{2+}: 10.8 ; \mathrm{Cu}^{2+}: 8.3$, respectively), in the case of ppo the $N, N^{\prime}$ coordination is encountered for the soft $\mathrm{Pd}^{2+}(6.8 \mathrm{eV})$, the hard $\mathrm{Ni}^{2+}$ centre $(8.5 \mathrm{eV})$ inducing $N, O$ coordination to ppo. This apparently conflicting conduct has presumably to be ascribed to the intrinsic electronic features of the oxazolidine and the oxazine ligands.

The different coordination modes of ppo towards Pd(II) and $\mathrm{Ni}(\mathrm{II})$ are summarised in Scheme 2.

Semi-empirical calculations (PM6 model) on the energetic levels of the five possible isomers deriving from the $\mathrm{N}, \mathrm{O}$-coordination of two ppo ligands to a ' $\mathrm{NiCl}_{2}$ ' framework show that the isomer characterised via $\mathrm{X}$-ray analysis is effectively the lowest in energy. Optimisation with the $\mathrm{COSMO}^{18}$ model in acetonitrile shows that all other possible isomers are separated by more than $40 \mathrm{~kJ} \mathrm{~mol}^{-1}$ from 2 (Fig. 4), reasonably ensuring that crystals used in the X-ray study are representative of the isolated bulk. A similar trend was also found from an in vacuo geometry optimisation (ESI $\dagger$ ).

Octahedral complexes of nickel(II) are typically high spin paramagnetic species $(S=1)$, hence their NMR spectra are often either not reported ${ }^{19}$ or recorded by opening the spectral window to remedy by signals broadening and downfield shift. ${ }^{20}$ In complex $\left[\mathrm{Ni}(\mathrm{N}, \mathrm{O} \text {-ppo })_{2} \mathrm{Cl}_{2}\right]$, the $\mathrm{Ni}-\mathrm{N}$ and $\mathrm{Ni}-\mathrm{O}$ distances $(2.055(4) \AA$ 


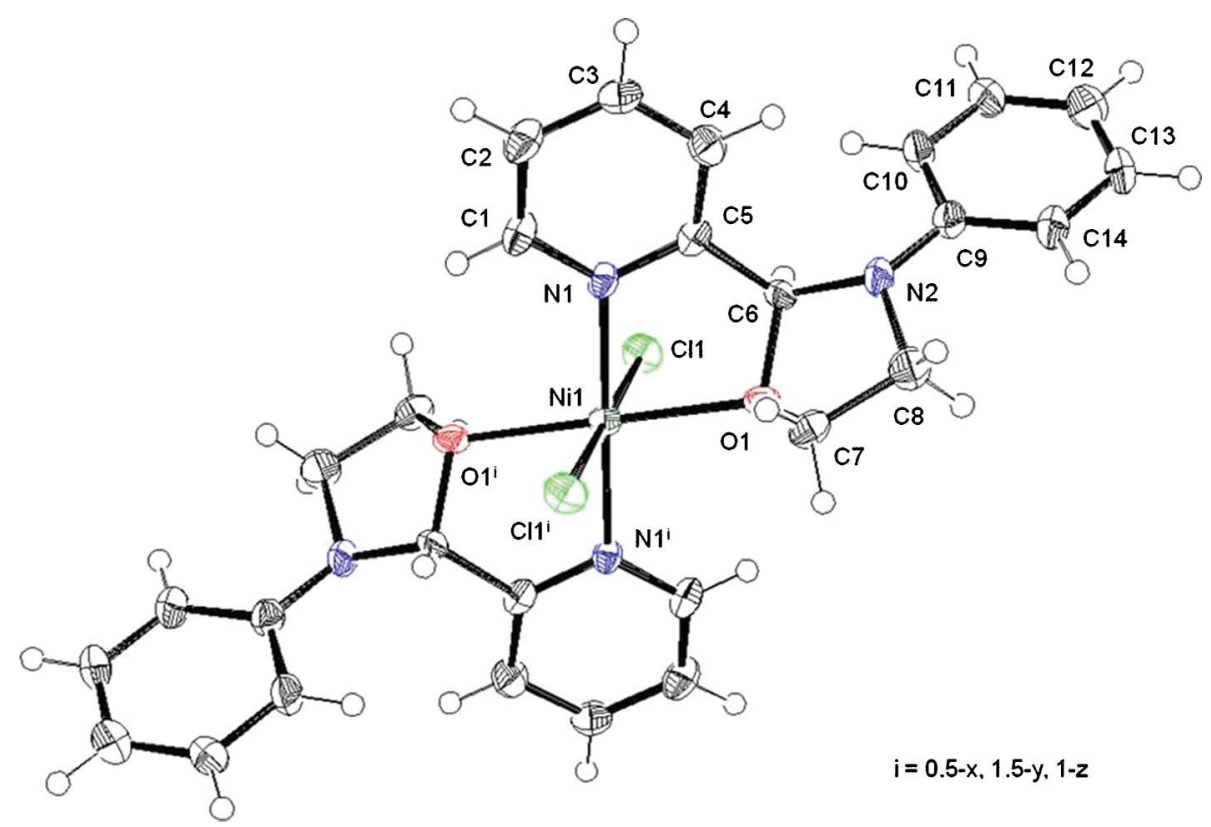

Fig. 3 ORTEP drawing of $2(50 \%$ probability level ellipsoids) with selected bond lengths ( $⿱$ ) $)$ and angles $\left({ }^{\circ}\right)$ : Ni1-Cl1 2.3857(14), Ni1-N1 2.055(4), Ni1-O1 2.167(3); Cl1-Ni1-N1 91.17(12), Cl1-Ni1-N1 88.83(12), Cl1-Ni1-O1 87.13(10), Cl1-Ni1-O1 ${ }^{i}$ 92.87(10), N1-Ni1-O1 78.82(15), N1-Ni1-O1 $101.18(15)$.

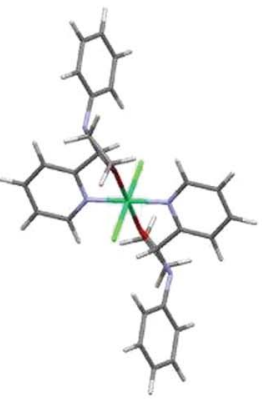

ttt- $\left[\mathrm{Ni}(\mathbf{p p o})_{2} \mathrm{Cl}_{2}\right]-\mathrm{opt}$

(0)

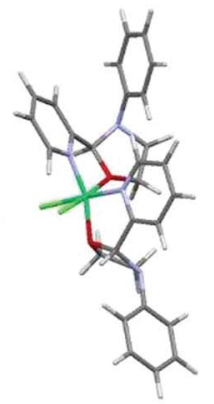

ccc- $\left[\mathrm{Ni}(\mathrm{ppo})_{2} \mathrm{Cl}_{2}\right]$

(43.3)

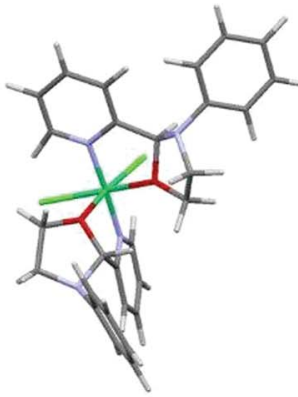

$t c c-\left[\mathrm{Ni}(\mathrm{ppo})_{2} \mathrm{Cl} \mathrm{l}_{2}\right]$

(63.8)

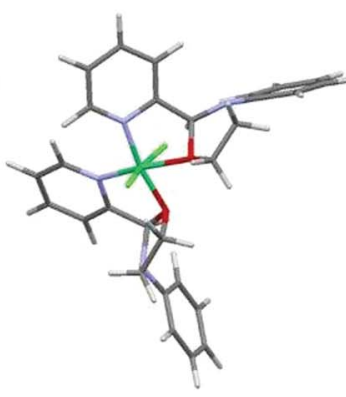

cct-[Ni(ppo $\left.)_{2} \mathrm{Cl}_{2}\right]$

(64.3)

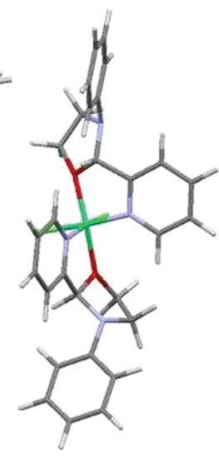

$\mathrm{Ctc}-\left[\mathrm{Ni}\left(\mathrm{ppo}_{2} \mathrm{Cl}_{2}\right]\right.$

(68.7)

Fig. 4 Optimised geometries of possible isomers of $\mathbf{2}$ and relative energy $\left(\mathrm{kJ} \mathrm{mol}^{-1}\right)$ with respect to 2-opt.
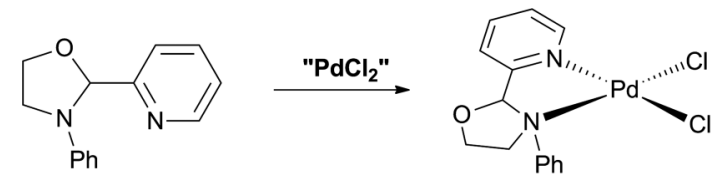

ppo

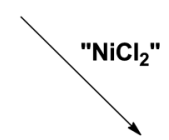

$\left[\operatorname{Pd}\left(N, N^{\prime}-\mathbf{p p o}\right) \mathrm{Cl}_{2}\right](\mathbf{1})$

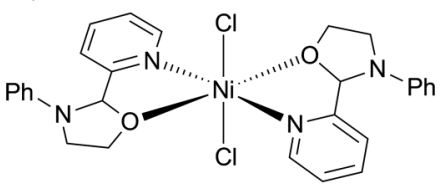

$\left[\mathrm{Ni}(\mathrm{N}, \mathrm{O}-\mathrm{ppo})_{2} \mathrm{Cl}_{2}\right](2)$

Scheme 2 Coordination of ppo towards $\mathrm{PdCl}_{2}$ and $\mathrm{NiCl}_{2}$ fragments. and 2.167(3) A, respectively, Fig. 3) are in the range expected for high-spin $\mathrm{Ni}(\mathrm{II})$ compounds. ${ }^{21}$ Accordingly, the ${ }^{1} \mathrm{H}$ NMR spectrum registered at room temperature in $\mathrm{CD}_{2} \mathrm{Cl}_{2}$ gives very broad undefined signals, thus confirming the octahedral high-spin nature of complex $\mathbf{2}$ in solution. Variable temperature magnetic moment measurements using solution ${ }^{1} \mathrm{H}$ NMR (Evans method) do not show any marked changes in the magnetic moment in the range $-45{ }^{\circ} \mathrm{C}$ to $35^{\circ} \mathrm{C}, \mu_{\text {eff }}$ being comprised between 2.87 and $3.05 \mu_{\mathrm{B}}(\mathrm{ESI} \dagger)$. The spin-only theoretical value for an octahedral $\mathrm{Ni}$ (II) centre having two unpaired electrons is $2.83 \mu_{\mathrm{B}}$, very close to the experimental data obtained with $\mathbf{2}$ (the methodology for magnetic moment measurement is summarised in the Experimental). Accordingly, we can conclude that the octahedral species is predominant over the whole range of temperatures. This finding is somehow corroborated by the lesser catalytic performances of crowded $\left[\mathrm{Ni}(\mathrm{N}, \mathrm{O} \text {-ppo })_{2} \mathrm{Cl}_{2}\right]$ species in aza-Michael reactions, when compared to the higher activity of the square planar $\left[\operatorname{Pd}\left(N, N^{\prime}\right.\right.$ ppo) $\mathrm{Cl}_{2}$ ] at low temperatures (vide infra). 


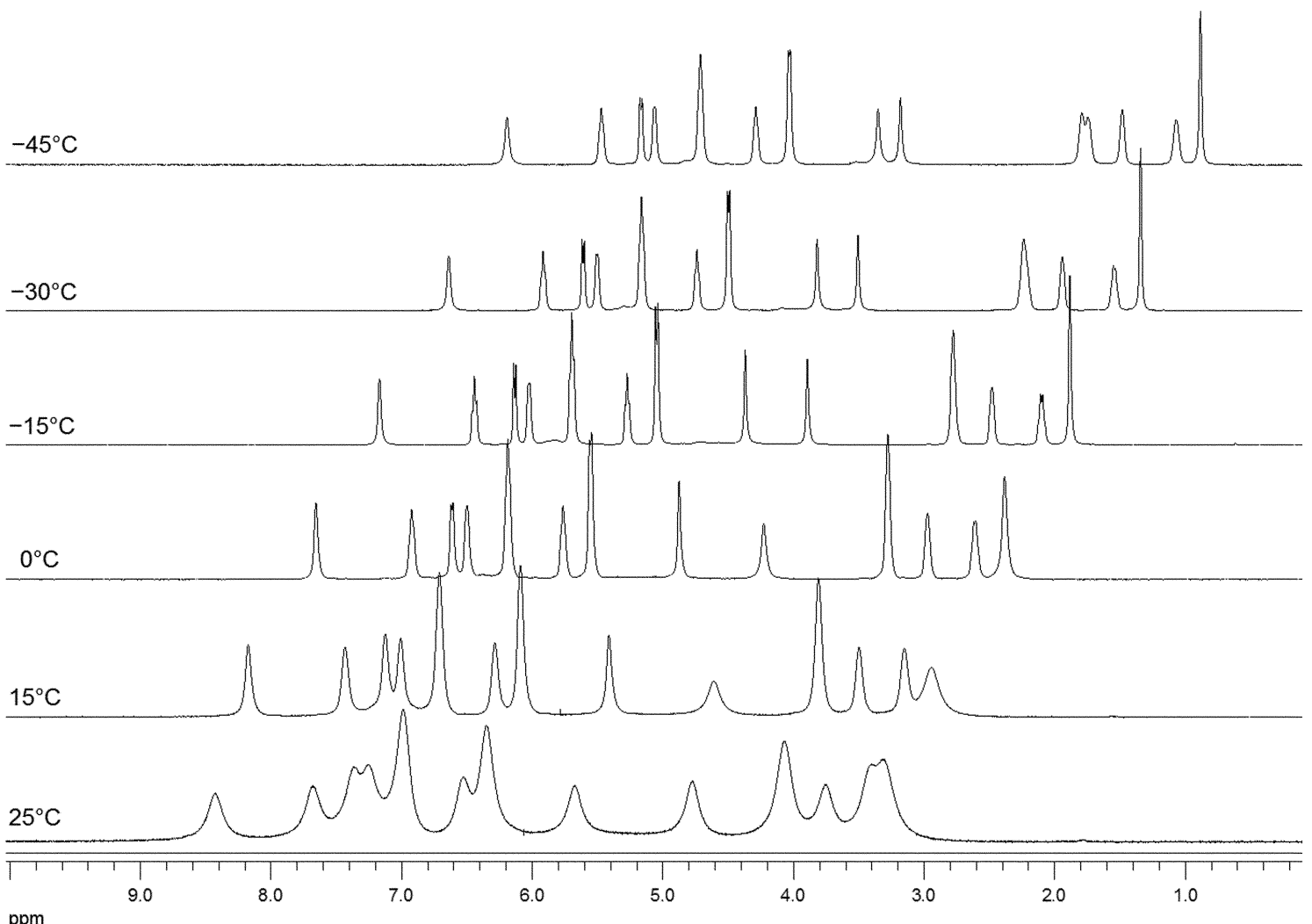

Fig. $5{ }^{1} \mathrm{H}$ VT NMR $\left(\mathrm{CD}_{3} \mathrm{OD}\right)$ of compound 2 (the spectra are shifted by $0.5 \mathrm{ppm}$ ).

Differently, the ${ }^{1} \mathrm{H}$ NMR of 2 registered in $\mathrm{CD}_{3} \mathrm{OD}$ at room temperature shows a pattern of resonances attributable to ppo. Even though the signals are not well-resolved, we tentatively carried out an interpretation of the spectrum by a comparison with the free ligand and consequently the signal at $5.67 \mathrm{ppm}$ is attributed to $\mathrm{H}-2$, whereas the three resonances at $3.40(1 \mathrm{H})$, $3.76(1 \mathrm{H})$ and $4.07(2 \mathrm{H})$ ppm are assigned to $\mathrm{H}_{\mathrm{a}}-4, \mathrm{H}_{\mathrm{a}}-5$ and $\mathrm{H}_{\mathrm{b}}$ $4 / 5$, respectively $(\mathrm{ESI} \dagger)$. Afterwards, a variable temperature NMR experiment has been performed, lowering the temperature from $25^{\circ} \mathrm{C}$ to $-45^{\circ} \mathrm{C}$ by 10 -to- 15 -degree intervals (Fig. 5). Couplings in the aromatic region firstly appear at $0{ }^{\circ} \mathrm{C}$, but a better resolution is obtained at $-15^{\circ} \mathrm{C}$, where nearly all the multiplicities emerge. Moreover, on further lowering the temperature to $-45^{\circ} \mathrm{C}$ the separation of the signal centred at $4.07 \mathrm{ppm}$ occurs, thus allowing discrimination between $\mathrm{H}_{\mathrm{b}}-4$ (4.18 ppm) and $\mathrm{H}_{\mathrm{b}}-5$ (4.23 ppm). The sharpening of the signals at low temperature does not derive from the conversion of $\left[\mathrm{Ni}(\mathrm{N}, \mathrm{O} \text {-ppo })_{2} \mathrm{Cl}_{2}\right]$ into a diamagnetic species. Indeed, the magnetic moment of 2 measured in $\mathrm{CD}_{3} \mathrm{OD}$ at $25^{\circ} \mathrm{C}$, $0{ }^{\circ} \mathrm{C}$ and $-45{ }^{\circ} \mathrm{C}$ spoke for a nickel atom with two unpaired electrons over the whole range of temperatures, $\mu_{\text {eff }}$ being 2.73, 2.81 and $2.94 \mu_{\mathrm{B}}$, respectively (ESI $\dagger$ ). Narrow line widths in ${ }^{1} \mathrm{H}$ NMR of paramagnetic nickel(II) complexes are rationalised in terms of fast relaxation times involving electron-spin relaxation. ${ }^{22}$ Moreover, the value of line widths for complex $\mathbf{2}$ is very close to that observed for free ppo $(8-9 \mathrm{~Hz})$, then it is supposed that the unpaired electrons flip so rapidly with respect to the molecular motion that their effect on the nuclear relaxation time is partially averaged out. ${ }^{23}$ Further studies will hopefully help to better elucidate this feature in the case of compound $\mathbf{2}$, especially with regards to the solvent effect on this mechanism.

\section{Aza-Michael catalytic reactions}

Complexes $\mathbf{1}$ and $\mathbf{2}$ have been tested as catalysts in the conjugate addition of aliphatic amines to $\alpha, \beta$-unsaturated ketones. This reaction, known as aza-Michael addition, is one of the most efficient methods to access $\beta$-amino carbonyl compounds, among which $\beta$-amino acids and $\beta$-lactams constitute an important target due to their pharmacological and synthetic importance. ${ }^{24}$ Thus, many efforts have been devoted in the last decades to develop new catalysts for this reaction, ${ }^{25}$ with special attention to its asymmetric variation. ${ }^{26}$

In this context, we decided to explore the catalytic activity of complexes $\left[\mathrm{Pd}\left(N, N^{\prime}\right.\right.$-ppo $\left.) \mathrm{Cl}_{2}\right]$ and $\left[\mathrm{Ni}(N, O \text { ppo })_{2} \mathrm{Cl}_{2}\right]$ in the conjugate addition of aliphatic secondary amines $\left(\mathrm{Me}_{2} \mathrm{NH}\right.$, piperidine, morpholine) to $\alpha, \beta$-unsaturated ketones. In this specific case, $(E)$ 4-phenylbut-3-en-2-one (benzalacetone) was used as a reference substrate (Scheme 3).

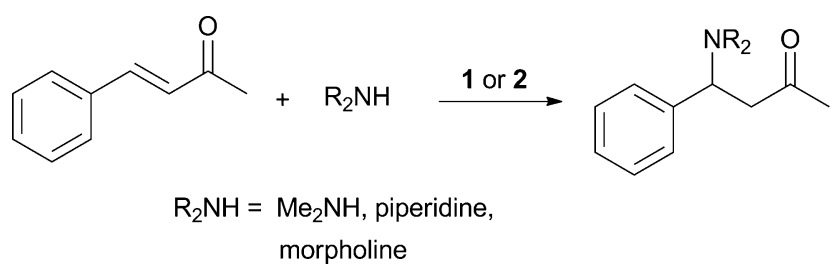

Scheme 3 Aza-Michael reactions catalysed by complexes 1 and 2.

The catalyst was dissolved in anhydrous THF in the presence of benzalacetone $(1: 100$ to the metal) and the reaction temperature was kept at $20{ }^{\circ} \mathrm{C}$; then, the aliphatic amine was added $(1: 100$ to 
Table 1 Conjugate addition of secondary aliphatic amines to benzalacetone catalysed by $\left[\mathrm{Pd}\left(N, N^{\prime}\right.\right.$-ppo $\left.) \mathrm{Cl}_{2}\right](\mathbf{1})$ and $\left[\mathrm{Ni}(N, O \text {-ppo })_{2} \mathrm{Cl}_{2}\right](\mathbf{2})^{a}$

\begin{tabular}{|c|c|c|c|c|}
\hline Entry & Catalyst & Amine & Product & Yield $^{b}(\%)$ \\
\hline 1 & 1 & piperidine & & 92 \\
\hline
\end{tabular}

$1 \quad$ morpholine

3

$$
1
$$

dimethylamine

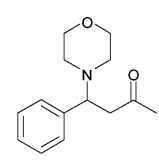

86

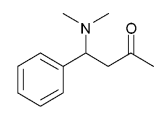

4

2

piperidine

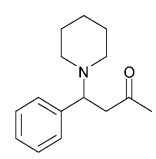

5

2

morpholine

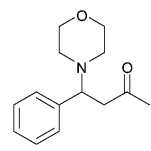

6

2

dimethylamine

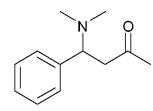

$7^{c}$

1

piperidine

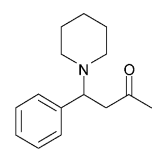

8

2

piperidine

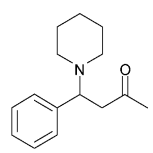

palladium(II) and nickel(II) studied. The derived complexes have been characterised by X-ray single crystal analysis, showing different chelating modes of ppo depending on the metal. A $N, N^{\prime}-$ coordination in the square planar palladium species $\left[\mathrm{Pd}\left(N, N^{\prime}-\right.\right.$ ppo $\left.\mathrm{Cl}_{2}\right]$ and a $N, O$-coordination towards nickel in $[\mathrm{Ni}(N, O$ ppo $\left.)_{2} \mathrm{Cl}_{2}\right]$ have been observed. In this latter compound, together with the two chloride ions, the nickel centre is surrounded by two ppo ligands, presenting an octahedral environment. These complexes have been tested as catalyst in the conjugate addition of aliphatic amines to benzalacetone, giving moderate-to-high yields of conversion under mild conditions.

\section{Experimental}

\section{Materials}

All reactions were carried out under nitrogen using standard Schlenk techniques. The solvents were dried and distilled according to standard procedures prior to use. $\mathrm{NiCl}_{2} \cdot 6 \mathrm{H}_{2} \mathrm{O}$, $\mathrm{K}_{2} \mathrm{PdCl}_{4}$, 2-anilino ethanol, 2-pyridinecarboxaldehyde and $(E)$ 4-phenylbut-3-en-2-one (Aldrich) were used as purchased. All amines employed in the catalytic runs were taken from sealed bottles.

NMR spectra were recorded with an AVANCE 400 Bruker spectrometer at $400 \mathrm{MHz}$ for ${ }^{1} \mathrm{H}$ NMR and $100 \mathrm{MHz}$ for ${ }^{13} \mathrm{C}\left\{{ }^{1} \mathrm{H}\right\}$ NMR. Chemical shifts are given as $\delta$ values in ppm relative to residual solvent peaks as the internal reference. $J$ values are given in $\mathrm{Hz} .{ }^{13} \mathrm{C}$ NMR spectra are ${ }^{1} \mathrm{H}$-decoupled and the determination of the multiplicities was achieved by the APT pulse sequence. Elemental analyses were obtained with a Perkin-Elmer CHN Analyser 2400 Series II. Quantitative analyses of products were performed on a Finningan Trace GC with a DB-5MS UI capillary column (30 m, $0.25 \mathrm{~mm})$ equipped with a Finningan Trace MS.

\section{Synthesis of 3-phenyl-2-(pyridin-2-yl)oxazolidine (ppo)}

${ }^{a}$ Catalyst $(0.025 \mathrm{mmol}):$ ketone $:$ amine $=1: 100: 100$; THF $(8 \mathrm{ml}), 20^{\circ} \mathrm{C}$. Internal standard: $\mathrm{C}_{6}\left(\mathrm{CH}_{3}\right)_{6}, 50 \mathrm{mg} .{ }^{b}$ Recorded after $24 \mathrm{~h}$ (GC-MS). ${ }^{c}$ Reaction temperature: $-30{ }^{\circ} \mathrm{C}$.

the metal), monitoring the evolution of the reaction via GC-MS. The results are reported in Table 1.

Compounds $\mathbf{1}$ and $\mathbf{2}$ give both good to high yields of conversion of benzalacetone into the corresponding substituted amines, at $20{ }^{\circ} \mathrm{C}$ (entry 1-6). They also demonstrate activity even at low temperatures $\left(-30{ }^{\circ} \mathrm{C}\right.$, entry $\left.7-8\right)$, albeit the conversion of benzalacetone into the corresponding adduct with piperidine remains minor with $\mathbf{2}$ as compared to $\mathbf{1}$ in these conditions. This last behaviour can be ascribed to steric effects: the square planar Pd(II) centre in $\mathbf{1}$ is less hindered than the octahedral Ni(II) atom in $\mathbf{2}$, where a chloride dissociation is required to generate an active catalytic species. The extent of this dissociation, and consequently the nickel-based catalyst activity, is reduced at low temperature.

\section{Conclusions}

In this study, the pyridinyloxazolidine ligand 3-phenyl-2-(pyridin2-yl)oxazolidine (ppo) has been prepared and coordination to
To a solution of 2-pyridinecarboxaldehyde $\left(1 \mathrm{ml}, d=1.126 \mathrm{~g} \mathrm{ml}^{-1}\right.$, $10.51 \mathrm{mmol})$ and 2-anilino ethanol $\left(1.32 \mathrm{ml}, d=1.094 \mathrm{~g} \mathrm{ml}^{-1}\right.$, $10.53 \mathrm{mmol})$ in ethanol $(20 \mathrm{ml}), 2-3$ drops of glacial acetic acid were added and the mixture was heated at $70{ }^{\circ} \mathrm{C}$ for $24 \mathrm{~h}$. Then the solvent was removed under reduced pressure, the residue dissolved in $\mathrm{CH}_{2} \mathrm{Cl}_{2}(20 \mathrm{ml})$ and washed with aqueous $\mathrm{NaHCO}_{3}$. The organic phase was dried over $\mathrm{Na}_{2} \mathrm{SO}_{4}$, filtered and the solvent evaporated to dryness. The crude oil was crystallised from pentane giving a light yellow solid (1.90 g, 80\%, mp $\left.77{ }^{\circ} \mathrm{C}\right)$. Found: C, 74.12; $\mathrm{H}, 6.51 ; \mathrm{N}, 12.10 \%$. Calc. for $\mathrm{C}_{14} \mathrm{H}_{14} \mathrm{~N}_{2} \mathrm{O}: \mathrm{C}, 74.31 ; \mathrm{H}, 6.24 ; \mathrm{N}$, $12.38 \% . \delta_{\mathrm{H}}\left(400 \mathrm{MHz}, \mathrm{CDCl}_{3}, 25^{\circ} \mathrm{C}\right): 3.63\left(1 \mathrm{H}, \mathrm{dd},{ }^{2} J_{\mathrm{HH}}=15.0\right.$, $\left.{ }^{3} J_{\mathrm{HH}}=7.5, \mathrm{H}_{\mathrm{a}}-4\right), 3.88\left(1 \mathrm{H}, \mathrm{m},{ }^{2} J_{\mathrm{HH}}=8.1,{ }^{3} J_{\mathrm{HH}}=6.3,{ }^{3} J_{\mathrm{HH}}=4.3\right.$ $\left.\mathrm{H}_{\mathrm{b}}-4\right), 4.26\left(2 \mathrm{H}, \mathrm{m},{ }^{2} J_{\mathrm{HH}}=8.3,{ }^{3} J_{\mathrm{HH}}=6.9,{ }^{3} J_{\mathrm{HH}}=4.7, \mathrm{H}_{\mathrm{a} / \mathrm{b}}-5\right), 5.96$ $(1 \mathrm{H}, \mathrm{s}, \mathrm{H}-2), 6.58\left(2 \mathrm{H}, \mathrm{dd},{ }^{3} J_{\mathrm{HH}}=4.1,{ }^{4} J_{\mathrm{HH}}=0.9, \mathrm{H}-7\right), 6.77(1 \mathrm{H}$, $\left.\mathrm{td},{ }^{3} J_{\mathrm{HH}}=7.1,{ }^{4} J_{\mathrm{HH}}=0.7, \mathrm{H}-9\right), 7.20\left(2 \mathrm{H}, \mathrm{dt},{ }^{3} J_{\mathrm{HH}}=8.0,{ }^{4} J_{\mathrm{HH}}=\right.$ $1.2, \mathrm{H}-8), 7.27\left(1 \mathrm{H}, \mathrm{m},{ }^{3} J_{\mathrm{HH}}=7.5,{ }^{3} J_{\mathrm{HH}}=4.9,{ }^{4} J_{\mathrm{HH}}=1.0, \mathrm{H}-11\right)$, $7.44\left(1 \mathrm{H}, \mathrm{d},{ }^{3} J_{\mathrm{HH}}=7.8, \mathrm{H}-13\right), 7.68\left(1 \mathrm{H}, \mathrm{dt},{ }^{3} J_{\mathrm{HH}}=7.8,{ }^{4} J_{\mathrm{HH}}=1.7\right.$, $\mathrm{H}-12), 8.69\left(1 \mathrm{H}, \mathrm{td},{ }^{3} J_{\mathrm{HH}}=4.8,{ }^{4} J_{\mathrm{HH}}=0.8, \mathrm{H}-10\right) . \delta_{\mathrm{C}}(100 \mathrm{MHz}$, $\left.\mathrm{CDCl}_{3}, 25{ }^{\circ} \mathrm{C}\right): 48.1$ (C-4), $65.9(\mathrm{C}-5), 92.6(\mathrm{C}-2), 113.3(\mathrm{C}-7)$, 118.0 (C-9), 121.2 (C-13), 123.7 (C-11), 129.2 (C-8), 137.0 (C-12), 145.5 (C-6), 149.7 (C-10), 159.1 (C-14). 


\section{Synthesis of $\left[\operatorname{Pd}\left(N, N^{\prime}-\right.\right.$ ppo $\left.) \mathrm{Cl}_{2}\right](1)$}

To a solution of $\mathrm{K}_{2} \mathrm{PdCl}_{4}(250 \mathrm{mg}, 0.766 \mathrm{mmol})$ in methanol $(20 \mathrm{ml})$, ppo (180 mg, $0.795 \mathrm{mmol}$ ) was added and the yellow-toorange suspension was stirred for $4 \mathrm{~h}$ at room temperature. Then the solid was filtered, washed with water, methanol and finally with diethylether and dried in vacuo (284 mg, 92\%). Found: C, 41.39; $\mathrm{H}, 3.71$; N, 7.03\%. Calc. for $\mathrm{C}_{14} \mathrm{H}_{14} \mathrm{Cl}_{2} \mathrm{~N}_{2} \mathrm{OPd}$ : C, 41.66; H, 3.50; $\mathrm{N}, 6.94 \% . \delta_{\mathrm{H}}\left(400 \mathrm{MHz}, \mathrm{CD}_{3} \mathrm{CN}, 25^{\circ} \mathrm{C}\right): 3.25\left(1 \mathrm{H}, \mathrm{m},{ }^{2} J_{\mathrm{HH}}=17.3\right.$, $\left.{ }^{3} J_{\mathrm{HH}}=8.8,{ }^{3} J_{\mathrm{HH}}=5.0, \mathrm{H}_{\mathrm{a}}-4\right), 4.46\left(1 \mathrm{H}, \mathrm{m},{ }^{2} J_{\mathrm{HH}}=11.2,{ }^{3} J_{\mathrm{HH}}=6.4\right.$, $\left.{ }^{3} J_{\mathrm{HH}}=3.5, \mathrm{H}_{\mathrm{a}}-5\right), 5.03\left(2 \mathrm{H}, \mathrm{m}, \mathrm{H}_{\mathrm{b}}-4\right.$ and $\left.\mathrm{H}_{\mathrm{b}}-5\right), 5.80(1 \mathrm{H}, \mathrm{s}, \mathrm{H}-2)$, $7.26\left(2 \mathrm{H}, \mathrm{dd},{ }^{3} J_{\mathrm{HH}}=8.5,{ }^{4} J_{\mathrm{HH}}=1.3, \mathrm{H}-7\right), 7.31\left(1 \mathrm{H}, \mathrm{td},{ }^{3} J_{\mathrm{HH}}=7.0\right.$, $\left.{ }^{4} J_{\mathrm{HH}}=1.3, \mathrm{H}-9\right), 7.36\left(2 \mathrm{H}, \mathrm{dt},{ }^{3} J_{\mathrm{HH}}=8.0,{ }^{4} J_{\mathrm{HH}}=1.8, \mathrm{H}-8\right), 7.63$ $\left(1 \mathrm{H}, \mathrm{m},{ }^{3} J_{\mathrm{HH}}=7.5,{ }^{3} J_{\mathrm{HH}}=5.9,{ }^{4} J_{\mathrm{HH}}=1.5 \mathrm{H}-11\right), 7.92(1 \mathrm{H}, \mathrm{dd}$, $\left.{ }^{3} J_{\mathrm{HH}}=8.0,{ }^{4} J_{\mathrm{HH}}=1.8, \mathrm{H}-13\right), 8.19\left(1 \mathrm{H}, \mathrm{dt},{ }^{3} J_{\mathrm{HH}}=7.9,{ }^{4} J_{\mathrm{HH}}=1.5\right.$, $\mathrm{H}-12) .8 .95\left(1 \mathrm{H}, \mathrm{dd},{ }^{3} J_{\mathrm{HH}}=5.8,{ }^{4} J_{\mathrm{HH}}=0.8, \mathrm{H}-10\right) . \delta_{\mathrm{C}}(100 \mathrm{MHz}$, $\left.\mathrm{CD}_{3} \mathrm{CN}, 25^{\circ} \mathrm{C}\right): 58.5(\mathrm{C}-4), 67.8$ (C-5), $101.9(\mathrm{C}-2), 121.6(\mathrm{C}-7)$, 125.2 (C-13), 127.6 (C-11), 128.0 (C-9), 130.6 (C-8), 142.4 (C-12), 146.6 (C-6), 151.4 (C-10), 160.6 (C-14).

Yellow crystals suitable for $\mathrm{X}$-ray investigation were obtained by slow diffusion of water into a $\mathrm{CH}_{3} \mathrm{CN}$ solution of $\mathbf{1}$.

\section{Synthesis of $\left[\mathrm{Ni}(\mathrm{N}, \mathrm{O}-\mathrm{ppo})_{2} \mathrm{Cl}_{2}\right](2)$}

A solution of $\mathrm{NiCl}_{2} \cdot 6 \mathrm{H}_{2} \mathrm{O}(300 \mathrm{mg}, 1.26 \mathrm{mmol})$ in acetonitrile $(15 \mathrm{ml})$ was treated with ppo $(580 \mathrm{mg}, 2.56 \mathrm{mmol})$ and the resulting suspension was stirred at $60^{\circ} \mathrm{C}$ for $8 \mathrm{~h}$. Then the solid was filtered, washed with acetonitrile, with diethylether and dried in vacuo (690 mg, 94\%). Found: C, 57.24; H, 4.61; N, 9.29\%. Calc. for $\mathrm{C}_{28} \mathrm{H}_{28} \mathrm{Cl}_{2} \mathrm{~N}_{4} \mathrm{O}_{2} \mathrm{Ni}$ : C, 57.77; $\mathrm{H}, 4.85 ; \mathrm{N}, 9.62 \%$.

Light green crystals suitable for $\mathrm{X}$-ray investigation were obtained by slow diffusion of diethylether at $25{ }^{\circ} \mathrm{C}$ into a DMF saturated solution of 2 .

\section{Magnetic moment measurements in solution}

According to the NMR method described by Evans, ${ }^{27}$ a solution of compound 2 (5-6 mg) in a mixture of $\mathrm{CD}_{2} \mathrm{Cl}_{2} /$ toluene (or $\mathrm{CD}_{3} \mathrm{OD} /$ toluene) $(95 / 5 v / v)$ was prepared. A portion of this solution was transferred into a melting point capillary tube, which was then sealed with PTFE-tape and dropped into an $\mathrm{NMR}$ tube containing the $\mathrm{CD}_{2} \mathrm{Cl}_{2} /$ toluene mixture. The chemical shift difference of the signal relative to the methyl on toluene between the inner and the outer tubes was measured at different temperatures. The following equations were used to calculate the molar susceptibility $\left(\chi_{\mathrm{M}}\right)$ and the magnetic moment $\mu_{\mathrm{eff}}$ (given in S.I. units):

$$
\begin{gathered}
\chi_{\mathrm{M}}=\frac{3 \cdot D}{1000 \cdot f \cdot c} \\
\mu_{\text {eff }}=798 \cdot \sqrt{T \cdot \chi_{\mathrm{M}}}
\end{gathered}
$$

where $\chi_{\mathrm{M}}$ is the molar susceptibility of the sample in $\mathrm{m}^{3} \mathrm{~mol}^{-1}, D$ is the difference in the chemical shift of toluene methyl in $\mathrm{Hz}, f$ is the frequency of operation of the spectrometer in $\mathrm{Hz}, c$ is the sample concentration in $\mathrm{mol} \mathrm{dm}{ }^{-3}, T$ is the temperature in $\mathrm{K}$.

\section{Computational details}

All of the calculations have been performed with the MOPAC2009 program package. ${ }^{28}$ The PM6 semiempirical method ${ }^{29}$ was used to optimise the geometry (vacuum and acetonitrile) of the $\left[\mathrm{Ni}(\mathbf{p p o})_{2} \mathrm{Cl}_{2}\right]$ species. For the sake of comparison, the geometry of complex 2 was optimised (2-opt) starting from the experimental Cartesian coordinates obtained by the X-ray diffraction study. Geometry optimisations in acetonitrile were performed using the COSMO dielectric continuum model as implemented in MOPAC2009 19 (MOPAC keywords: $\mathrm{ESP}=37.5$, $\mathrm{RSOLV}=1.3, \mathrm{NSPA}=$ 122). Graphics were obtained by the Jmol program package. ${ }^{30}$

\section{Aza-Michael reactions}

In a typical experiment, to a solution of the catalyst $(0.025 \mathrm{mmol})$ and benzalacetone $(2.5 \mathrm{mmol})$ in anhydrous THF $(8 \mathrm{ml}) \mathrm{kept}$ at $20{ }^{\circ} \mathrm{C}$, the amine $(2.5 \mathrm{mmol})$ was added and the proceeding reaction was monitored via GC-MS. All of the products are known compounds and were easily identified by comparison of their spectroscopic data with those reported in the literature (see ESI $\uparrow$ for mass spectra).

\section{Single-crystal X-ray structure analysis}

Crystals of $\mathbf{1}$ and $\mathbf{2}$ were mounted on a Stoe Image Plate Diffraction system equipped with a $\phi$ circle goniometer, using Mo-K $\alpha$ graphite monochromated radiation $(\lambda=0.71073 \AA)$ with $\phi$ range $0-200^{\circ}$. The structures were solved by direct methods using the program SHELXS-97, while the refinement and all further calculations were carried out using SHELXL-97. ${ }^{31}$ The H-atoms were included in calculated positions and treated as riding atoms using the SHELXL default parameters. The non-H atoms were refined anisotropically, using weighted full-matrix least-square on $F^{2}$.

Table 2 Crystallographic and structure refinement parameters for com-

\begin{tabular}{|c|c|c|}
\hline & 1 & 2 \\
\hline Chemical formula & $\mathrm{C}_{14} \mathrm{H}_{14} \mathrm{Cl}_{2} \mathrm{~N}_{2} \mathrm{OPd}$ & $\mathrm{C}_{28} \mathrm{H}_{28} \mathrm{Cl}_{2} \mathrm{~N}_{4} \mathrm{O}_{2} \mathrm{Ni}$ \\
\hline Formula weight & 403.57 & 582.15 \\
\hline Crystal system & Monoclinic & Monoclinic \\
\hline Space group & $P 2_{1} / c$ (no. 14$)$ & $C 2 / c($ no. 15$)$ \\
\hline Crystal colour and shape & Yellow block & Green block \\
\hline Crystal size & $0.23 \times 0.18 \times 0.15$ & $0.22 \times 0.17 \times 0.16$ \\
\hline$a / \AA ̊$ & $8.6308(6)$ & $23.437(5)$ \\
\hline$b / \AA$ & $12.3692(6)$ & $6.6280(10)$ \\
\hline$c / \AA$ & $15.1831(10)$ & $17.741(4)$ \\
\hline$\beta\left({ }^{\circ}\right)$ & $114.683(5)$ & $98.67(3)$ \\
\hline$V / \AA^{3}$ & $1472.79(16)$ & $2724.4(9)$ \\
\hline$Z$ & 4 & 4 \\
\hline$T / \mathrm{K}$ & $173(2)$ & $173(2)$ \\
\hline$D_{\mathrm{c}} / \mathrm{g} \mathrm{cm}^{-3}$ & 1.820 & 1.419 \\
\hline$\mu / \mathrm{mm}^{-1}$ & 1.618 & 0.941 \\
\hline Scan range $\left(^{\circ}\right)$ & $2.21<\theta<29.18$ & $1.76<\theta<29.19$ \\
\hline fflections & 3971 & 3659 \\
\hline Observed refls $[I>2 \sigma(I)]$ & 3546 & 1812 \\
\hline$R_{\mathrm{int}}$ & 0.0902 & 0.2128 \\
\hline Final $R$ indices $[I>2 \sigma(I)]^{a}$ & $0.0424, w R_{2} 0.0985$ & $0.0890, w R_{2} 0.1166$ \\
\hline$R$ indices (all data) & $0.0496, w R_{2} 0.1005$ & $0.1891, w R_{2} 0.1412$ \\
\hline Goodness-of-fit & 1.312 & 0.988 \\
\hline $\operatorname{Max}, \operatorname{Min} \Delta \rho / e\left(\AA^{-3}\right)$ & $0.856,-1.168$ & $0.453,-0.616$ \\
\hline
\end{tabular}
plexes $\mathbf{1}$ and $\mathbf{2}$

${ }^{a}$ Structures were refined on $F_{0}{ }^{2}: w R_{2}=\left[\Sigma\left[w\left(F_{0}{ }^{2}-F_{\mathrm{c}}{ }^{2}\right)^{2}\right] / \Sigma w\left(F_{0}{ }^{2}\right)^{2}\right]^{1 / 2}$, where $w^{-1}=\left[\Sigma\left(F_{0}{ }^{2}\right)+(\mathrm{a} P)^{2}+\mathrm{b} P\right]$ and $P=\left[\max \left(F_{0}{ }^{2}, 0\right)+2 F_{\mathrm{c}}{ }^{2}\right] / 3$. 
Crystallographic details are summarised in Table 2. Fig. 2 and 3 were drawn with ORTEP. ${ }^{32}$

\section{Acknowledgements}

Dr E. Alberti is greatly acknowledged for performing variable temperature NMR experiments. F. Bernasconi is also acknowledged for valuable experimental contributions.

\section{Notes and references}

1 D. Aguilà, E. Escribano, S. Speed, D. Talancón, L. Yermán and S. Alvarez, Dalton Trans., 2009, 6610-6625 and references therein.

2 C. A. Caputo and N. D. Jones, Dalton Trans., 2007, 4627-4640.

3 For recent reviews on catalytic applications of oxazoline-based complexes see: (a) G. C. Hargaden and P. J. Guiry, Chem. Rev., 2009, 109, 2505-2550; (b) R. Rasappan, D. Laventine and O. Reiser, Coord. Chem. Rev., 2008, 252, 702-714.

4 L. Neelakantan, J. Org. Chem., 1971, 36, 2256-2260.

5 E. Błocka, M. Jaworska, A. Kozakiewicz, M. Wełnak and A. Wojtczak, Tetrahedron: Asymmetry, 2010, 21, 571-577; R. W. Parrot and S. R. Hitchcock, Tetrahedron: Asymmetry, 2007, 18, 377-382.

6 C. Augier, L. Malara, V. Lazzeri and B. Waegell, Tetrahedron Lett., 1995, 36, 8775-8778.

7 Y. Okuyama, H. Nakano and H. Hongo, Tetrahedron: Asymmetry, 2000, 11, 1193-1198; M-J. Jin, J-A. Jung and S-H. Kim, Tetrahedron Lett., 1999, 40, 5197-5198.

8 A. Albinati, F. Lianza, H. Berger, C. Arz and P. S. Pregosin, Inorg. Chim. Acta, 1992, 198-200, 771-780.

9 H. Nakano, H. Takahashi, Y. Okuyama, C. Senoo, N. Tsugawa, Y. Suzuki, R. Fujita, K. Sasaki and C. Kabuto, J. Org. Chem., 2004, 69, 7092-7100; H. Nakano, Y. Okuyama, Y. Suzuki, R. Fujita and C. Kabuto, Chem. Commun., 2002, 1146-1147.

10 G. Ríos-Moreno, R. A. Toscano, R. Redón, H. Nakano, Y. Okuyama and D. Morales-Morales, Inorg. Chim. Acta, 2005, 358, 303-309.

11 S. A. Cardile, M. C. Jennings and N. D. Jones, Dalton Trans., 2006, $4672-4678$

12 G. A. Ardizzoia, S. Brenna, F. Castelli, S. Galli and N. Masciocchi, Inorg. Chim. Acta, 2010, 363, 324-329.

13 G. A. Ardizzoia, S. Brenna and B. Therrien, Eur. J. Inorg. Chem., 2010, $3365-3371$.

14 The monodentate coordination via the $N$ - or $O$ - atoms of the oxazolidine moiety or via the $\mathrm{sp}^{2}$ nitrogen of the pyridine ring should not be excluded, but are considered less probable due to chelation effects.

15 S. Soliman, H. Abdine and S. El-Nanaey, Aust. J. Chem., 1975, 28, 49-56.

16 K. Pihlaja, M. Juhàsz, H. Kivelä and F. Fülöp, Rapid Commun. Mass Spectrom., 2008, 22, 1510-1518.

17 E. T. J. Strong, S. A. Cardile, A. L. Brazeau, M. C. Jennings, R. McDonald and N. D. Jones, Inorg. Chem., 2008, 47, 10575-10586.

18 A. Klamt and G. Schümann, J. Chem. Soc., Perkin Trans. 2, 1993, 799-805.

19 L. Li, C. S. B. Gomes, P. T. Gomes, M. T. Duarte and Z. Fan, Dalton Trans., 2011, 40, 3365-3380; H. Liu, L. Zhang, L. Chen, C. Redshaw, Y. Li and W.-H. Sun, Dalton Trans., 2011, 40, 2614-2621; N. AndradeLópez, T. A. Hanna, J. G. Alvarado-Rodríguez, A. Luqueño-Reyes, B. A. Martínez-Ortega and D. Mendoza-Espinosa, Polyhedron, 2010, 29, 2304-2310; C. Ochs, F. E. Hahn and T. Lügger, Eur. J. Inorg. Chem., 2001, 1279-1285; B. Korybut-Daszkiewicz, P. Gluziński, J. Krajewski, A. Kemme and A. Mishnev, Eur. J. Inorg. Chem., 1999, 263-268.

20 L. López-Banet, M. D. Santana, G. García, L. García, L. Lezama and J-P. Costes, Inorg. Chem., 2011, 50, 437-443; T. S. Lobana, P. Kumari,
R. Sharma, A. Castineiras, R. J. Butcher, T. Akitsu and Y. Aritake, Dalton Trans., 2011, 40, 3219-3228; K. Rudzka, A. M. Arif and L. M. Berreau, Inorg. Chem., 2008, 47, 10832-10840; M. D. Santana, L. López-Banet, G. García, L. García, J. Pérez and M. Liu, Eur. J. Inorg. Chem., 2008, 4012-4018; O. Rotthaus, V. Labet, C. Philouze, O. Jarjayes and F. Thomas, Eur. J. Inorg. Chem., 2008, 4215-4224; H. M. Alvarez, M. Krawiec, B. T. Donovan-Merkert, M. Fouzi and D. Rabinovich, Inorg. Chem., 2001, 40, 5736-5737; T. Yoshida and S. Kaizaki, Inorg. Chem., 1999, 38, 1054-1058; C. Dietz, F. W. Heinemann, J. Kuhnigk, C. Krüger, M. Gerdan, A. X. Trautwein and A. Grohmann, Eur. J. Inorg. Chem., 1998, 1041-1049.

21 O. Rotthaus, F. Thomas, C. Philouze, O. Jarjayes, E. Saint-Aman and J-L. Pierre, Chem.-Eur. J., 2006, 12, 6953-6962; S. Mukhopadhyay, D. Mandal, D. Ghosh, I. Goldberg and M. Chaudhury, Inorg. Chem., 2003, 42, 8439-8445; G. Psomas, A. J. Stemmler, C. Dendrinou-Samara, J. J. Bodwin, M. Schneider, M. Alexiou, J. W. Kampf, D. P. Kessissoglou and V. L. Pecoraro, Inorg. Chem., 2001, 40, 1562-1570; H. Duval, V. Bulach, J. Fischer and R. Weiss, Inorg. Chem., 1999, 38, 5495-5501; J. C. Jeffrey and M. D. Ward, J. Chem. Soc., Dalton Trans., 1992, 2119-2120.

22 D. Forster, Inorg. Chim. Acta, 1968, 2, 116-118; G. N. La Mar, J. Am. Chem. Soc., 1965, 87, 3567-3571.

23 R. E. Richards, Discuss. Faraday Soc., 1962, 34, 74-76; D. R. Eaton, A. D. Josey, W. D. Phillips and R. E. Benson, J. Chem. Phys., 1963, 39, 3513-3518 and references therein.

24 E. Juaristi and V. A. Soloshonok, Enantioselective Synthesis of $\beta$-Amino Acids, 2nd Edn, John Wiley \& Sons, Inc, Hoboken, New Jersey, 2005; I. Reboule, R. Gil and J. Collin, Tetrahedron Lett., 2005, 46, 7761-7764; P. A. Magriotis, Angew. Chem., Int. Ed., 2001, 40, 4377-4379.

25 See for example: X. Ai, X. Wang, J-M. Liu, Z-M. Ge, T.-M. Cheng and R.-T. Li, Tetrahedron, 2010, 66, 5373-5377 and references cited therein; N. Azizi, R. Baghi, H. Ghafuri, M. Bolourtchian and M. Hashemi, Synlett, 2010, 3, 379-382; K. De, J. Legros, B. Crousse and D. Bonnet-Delpon, J. Org. Chem., 2009, 74, 6260-6265; A-G. Ying, L. Liu, G-F. Wu, G. Chen, X-Z. Chen and W-D. Ye, Tetrahedron Lett., 2009, 50, 1653-1657; M. L. Kantam, M. Roy, S. Roy, B. Sreedhar and R. L. De, Catal. Commun., 2008, 9, 2226-2230; R. Varala, N. Sreelatha and S. R. Adapa, Synlett, 2006, 10, 1549-1553; A. T. Khan, T. Parvin, S. Gazi and L. H. Choudhury, Tetrahedron Lett., 2007, 48, 3805-3808; K. Surendra, N. S. Krishnaveni, R. Sridhar and K. R. Rao, Tetrahedron Lett., 2006, 47, 2125-2127; H. Firouzabadi, N. Iranpoor and F. Nowrouzi, Chem. Commun., 2005, 789-791; H. Firouzabadi, N. Iranpoor and A. A. Jafari, Adv. Synth. Catal., 2005, 347, 655-661; M. K. Chaudhuri, S. Hussain, M. L. Kantam and B. Neelima, Tetrahedron Lett., 2005, 46, 8329-8331; M. Pérez and R. Pleixats, Tetrahedron, 1995, 51, 8355-8362; G. Jenner, Tetrahedron Lett., 1995, 36, 233236.

26 See for example: J. Jiang, Y. Cai, W. Chen, L. Lin, X. Liu and X. Feng, Chem. Commun., 2011, 47, 4016-4018; L. Lykke, D. Monge, M. Nielsen and K. A. Jørgensen, Chem.-Eur. J., 2010, 16, 13330-13334; D. Enders, C. Wang and J. X. Liebich, Chem.-Eur. J., 2009, 15, 11058 11076; P. R. Krishna, A. Sreeshailam and R. Srinivas, Tetrahedron, 2009, 65, 9657-9672; X. Lu and L. Deng, Angew. Chem., Int. Ed., 2008, 47, 7710-7713; A. Scettri, A. Massa, L. Palombi, R. Villano and M. R. Acocella, Tetrahedron: Asymmetry, 2008, 19, 2149-2152; N. Yamagiwa, H. Qin, S. Matsunaga and M. Shibasaki, J. Am. Chem. Soc., 2005, 127, 13419-13427.

27 D. F. Evans, J. Chem. Soc., 1959, 2003-2005.

28 J. J. P. Stewart, MOPAC2009, Stewart Computational Chemistry, Colorado Springs, CO, USA 2009, http://OpenMOPAC.net.

29 J. J. P. Stewart, J. Mol. Model., 2007, 13, 1173-1213.

$30 \mathrm{Jmol}$ : an open-source Java viewer for chemical structures in $3 \mathrm{D}$, http://www.jmol.org/.

31 G. M. Sheldrick, Acta Crystallogr., Sect. A: Found. Crystallogr., 2008, 64, 112-122.

32 L. J. Farrugia, J. Appl. Crystallogr., 1997, 30, 565. 